\title{
電氣製 鋼
}

第八巻第二栫

昭和七年二月十五日

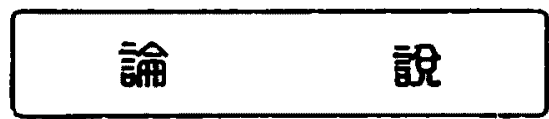

\section{鐵錆 の 研 究(其-)}

大氣中に於けろ濕度そ鐵錆及び各種鐵錆の性質

會員理學士 遠 藤 坴 造

目

$\$$ I. 䋹

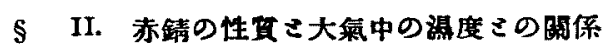

(A) 赤锖生成の機軓

（B）水中に於け万赤锖の䧣壁作用

(C) 大氣中に於け万赤錆の酸生及び渴度さ赤 錆さの開係

\section{次}

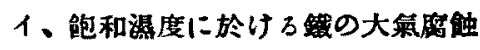

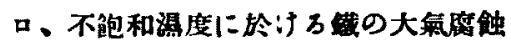

八、赤錆中の水分さ臨界梁度さの网係

\$III. 黑錆さ大氣中に於け万防蝕作用

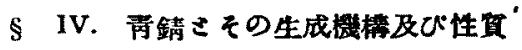

$\S$ V. 總括

\section{§ I. 精文}

衆人の躰によく知れる如く、鐵は大氣中に於て容易に濕氣即ち水分と酸素とを取つて赤いが サガサした所謂赤錆をその表面に作る、何ぜあんな赤靕が出來るかと云ふと、難解な理論を拢

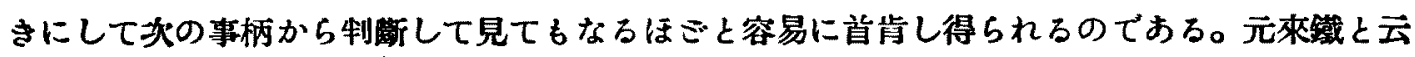

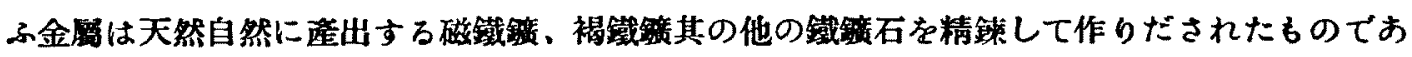

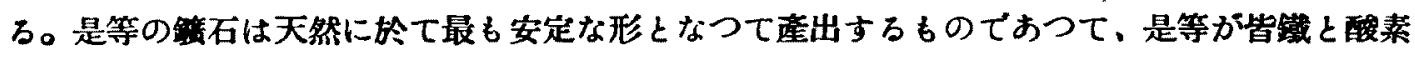
とが化學的に結合して出來てるるものである、それを人々が色々の化學的方法によつて酸素を 無理に鐵から取り離して鐵と云ふ金屬にしたるのであるから、之を空氣中に出しておけばヌ元 の篦石の如く、酸素と結ひついて赤い錆となる事は誰人が考へても理の當然でらる事が制ろ譯 である。 
今ァルiニウムとか、鉛と云つた㧼な金屬を空氣中に出しておくと鐵と同㧼に直くに錆びる、 しかしこの锖は表面に一樣に薄く氣密にしかる丈夫に出來ろので、一度金嫂面を全部この錆で 蔽つてしまふと、もうその下面にある金属が錆びてゆく樣な事はない、故に吾人にとつて誠に 結椦な錆と云はなくてはならない。然るに前記鐵の赤錆は鐵面に一梠に丈夫に出來ない、其の 上多孔筧でしかも水分を吸ひ易いものであるから一點でもこの赤錆が出來ると大氣の㬎度が簬 點以下におつても傍から摭り、內部の力へもグングンと哙ひ込んでゆくるのでおつて、錆の登 生を促進せしめろと云ふ誠に仕末の惡いものである。

貝際日常吾人の目に映ずる建築物に使用されてるろ鐵鎆材料が赤錆を生じてるないものは㱠 んミ存在しない值で、辕と赤錆とは離るべからざる共存物である事は世人の等しく認のろ所て

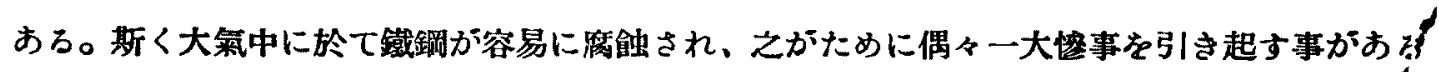

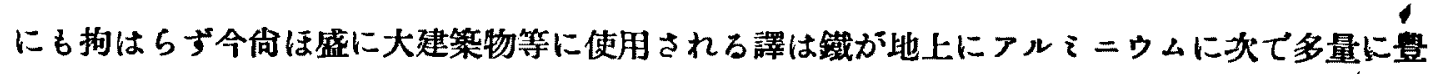
富に存在し、しかも古くから筡鐵作業が發達して來てろろので極めて安價に得られろと同時に

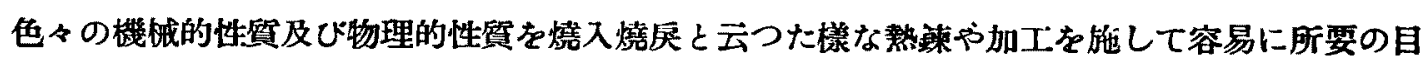
的にする事が出來るからである。石造や煉瓦の建築物等が數百年の長年月風雨に懪されても向 ほ教化せずに好良な狀態に存在してはるろが、是等の岩石煉瓦類は延伸萃が小さく、所要の强 力を出すためには膨大な容碃を要し、慥つて過大な重量となる缺點をもち、侣は且つ可塑性、 柔軟性等に缺乏してるろから大建築物には不適當である、てのため近年に到つて鐵筇コンクッ ートの如きものが使用されろに到つた所以である。斯く鐵筋にしろ、大建築物の骨組金局材料 は岩石類のもつ缺點がなく就中鐵銅は上逝の理由によつて工゙業建䓩材料として最も通したもの であるが、たミこの腐蝕せられ易い事が一大缺點である、故にこの缺點を完全に防止し得ろ事 が出來れば全く理想的のものなる事は論を㑨たない。この防蝕研究については腐蝕の原理を明 かにし且つ使用塲所に起る各種の因子をよく检べて通宜な手段を施す譯であるが、是等の事筫 については本文の主旨から遠ざかるので茲には記述を避けろ事とする。

\begin{tabular}{|c|c|}
\hline 化 合 物 & 分量 (\%) \\
\hline 第二酸 化 鐵 & 92.90 \\
\hline 第一酸化塗 & 6.18 \\
\hline 第一宸酸鐵 & 0.62 \\
\hline 理酸 & 0.12 \\
\hline$>=\epsilon=>$ & 痕 跡 \\
\hline 炭酸カルシウム & 0.26 \\
\hline
\end{tabular}

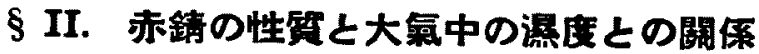

扱て話を厌してこの赤錆であるがその容積は鐵のそれ に比して大なるものであるから、鐵鈵が大氣中に於て長 年月の間に全體が膨大な驰緩したものになつてしまふの である。この赤錆の成分を分析して見ろと大體は第 1 表 に示す如くで、含水酸化鐵で强磁性をもつものであか ら第一酸化鐵が共存する事は明かである。そして之が共

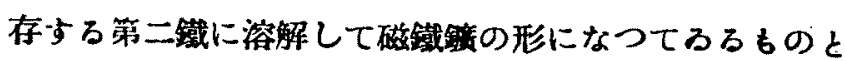


考へられる。炏にこの赤輤は如何にして出來るかと云ふ事であるか、之は大氧中でも水中に於て b生成の原理は同一で、水中に於けるものは充分に水分をとつて完全に水酸化第二鐵 $\mathrm{Fe}(\mathrm{OH})_{3}$ の形になつてるろに過ぎない。この生成原理に就ては著者が本誌に於ても展々記述した所がお らから茲には極めて简單に記迅してておく事にする。而して水中に於て赤錆の生成する機構在迅

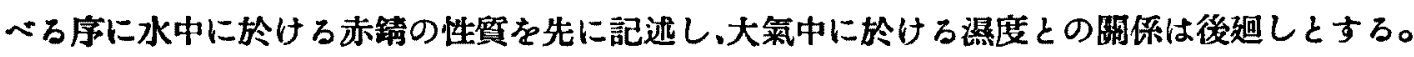

\section{（A） 赤錆生成の機構}

水は一種の電解賀て次式の如くに電離してるふ。

$$
\mathrm{H}_{2} \mathrm{O} \rightleftarrows \mathrm{H}^{+}+\mathrm{OH}^{-}
$$

この際水素1オンは他の多くの金屬イオンの如くに陽電氣を荷つてるる事は算知の事でおる。 今この中に水素より一居陽性の金虽例へば本問題の鐵を入れたとすると鐵の電溶栥が水素のそ れより海かに大であろため鐵の一部分から鐵は溶けて瀻イオンとなる、この際鐵面は全く均一 とは考へられないので部分的に除陽丽極を生じ陽極となつた所から鐵が水中に溶け込む。(水中 で鐵面に陰陽兩極の生成する事は水中の酸素の浱癷によつて生成される事が曹通である。然る 時は陰極に水素を放電して水素皮膜を作ろ。鐵イオンは水酸基イオンと結合して水酸化第一鐵 となる、この物は水に僅かにとけるので一部分は鐵面に沈澱する、而してその性資はァルカッ 性のものでおろから陰極部を水素で双昜極部をこの水酸化第一鐵で全部嫩つてしまへば鐵は最 早溶解してこない。然るに水中には空筆中の酸素が溶け込んでるるのてこれが陰極に遊離した 水素を酸化して水となし、一方水酸化第一鐵を酸化して水酸化第二鐵とする、このものか所謂

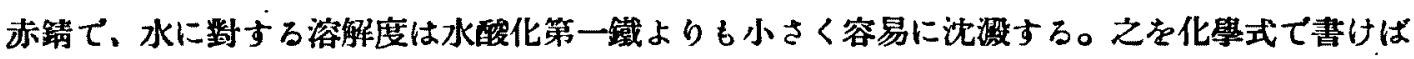
头の如くでる。

$$
\begin{aligned}
& \mathrm{H}_{2} \mathrm{O} \rightleftarrows \mathrm{H}^{+}+\mathrm{OH}^{-}, \quad \mathrm{Fe}+2 \mathrm{H}^{+}=\mathrm{Fe}^{++}+\mathrm{H}_{2} \\
& \mathrm{H}_{2}+\mathrm{O}=\mathrm{H}_{2} \mathrm{O}, \quad \mathrm{Fe}^{++}+2(\mathrm{OH})=\mathrm{Fe}(\mathrm{OH})_{2} \\
& 4 \mathrm{Fe}(\mathrm{OH})_{2}+2 \mathrm{H}_{2} \mathrm{O}+\mathrm{O}_{2}=4 \mathrm{Fe}(\mathrm{OH})_{3}
\end{aligned}
$$

故に水中に於ける酸素によつて水素皮膜も水酸化第一鐵皮膜も破壊せられるため又陰陽雨極が 表はれ鐵の溶解が進行して上記方程式の示す反應を繰り返してゆく、鐵面が全部赤錆によつて

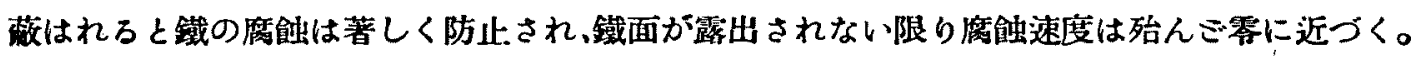

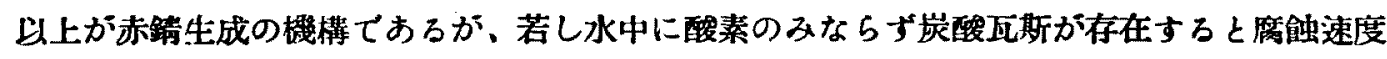
は一房速かになる。之は炭酸が出來て水素イオンの量が多くなると同時に一方生成されて未だ 第二鐵にならないでるる水酸化第一鐵を中和するのて水酸化第一鐵皮膜を一居早く破垻する性 能があ万事から考へて當然の事である。又次の化學反應のあ万事も當然に考へられろ。但し炭 酸瓦斯の存在が腐蝕に必要缺くべからざるものであると云ふ譯のものではない。 


$$
\begin{aligned}
& \left\{\begin{array}{l}
2 \mathrm{Fe}+2 \mathrm{H}_{2} \mathrm{CO}_{3}=2 \mathrm{FeCO}_{3}+4 \mathrm{H} \\
4 \mathrm{FeCO} \\
4 \mathrm{H}+\mathrm{O}_{2}+10 \mathrm{O}_{2} \mathrm{O}=4 \mathrm{Fe}(\mathrm{OH})_{3}+4 \mathrm{H}_{2} \mathrm{CO}_{3} \mathrm{O} \\
\mathrm{FeCO}+\mathrm{CO}_{2}+\mathrm{H}_{2} \mathrm{O}=\mathrm{Fe}\left(\mathrm{HCO}_{3}\right)_{2} \text { 溶解性重炭酸第一鐵 }
\end{array}\right. \\
& \begin{array}{l}
4 \mathrm{Fe}\left(\mathrm{HCO}_{3}\right)_{2}+\mathrm{O}_{2}+2 \mathrm{H}_{2} \mathrm{O}=4 \mathrm{Fe}(\mathrm{OH})_{3}+8 \mathrm{CO}_{2}
\end{array} \\
& \mathrm{Fe}\left(\mathrm{HCO}_{3}\right)_{2}=\mathrm{FeO}+2 \mathrm{CO}_{2}+\mathrm{H}_{2} \mathrm{O}
\end{aligned}
$$

夷にこの赤錆が鐵面に存在してるろと如何なろ作用なするか後述する黑鈹（黑錆）の作用と 比較して興味樑いものがある。

\section{（B）水中に於けろ赤錆の隔壁作用}

今鐵をよく研磨しで鏡の如くし油脂を除去した清淨面を持つて來る、この上を赤锖をもつて

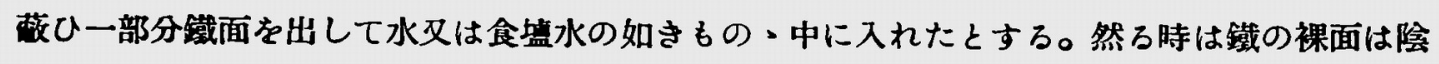
極となり之と接觸する赤錆の下面にあろ鐵の部分が陽極となつてこの部分が先つ浸蝕される。 この現象は何故に起ろかと云へば赤錆が隔壁となつて赤錆下の鐵面に擴散する溶解酸素の浱度 と裸面に擴散する酸素の浱度に大差があるからで、裸面に達する酸素量が多く、赤錆下の面は この隔壁が酸素の擴散を阻止するのて茲に酸素の涱淡電池を生ずろ。この浱淡電池に於て酸素 量の多い所が陰極に、少い所が陽極になろ事賽は Evans 氏を始め著者(1) の賽臨によつても明 かな事賽である。即ち上記試片に於て裸面の隣りで赤錆下面の鐵が腐蝕してゆく、若しこの裸 面の面栍が小さい塲合には腐蝕初期に於て長時間そのま・に保持されろが長日月の後には生成 されろ錆が撗散して全部赤錆で罱はれる。

貝際に著者は電解鐵の薄板を長さ 7 粴、幅 2 粝位にきりとり更に長さを 3.5 糎つ・・に分し

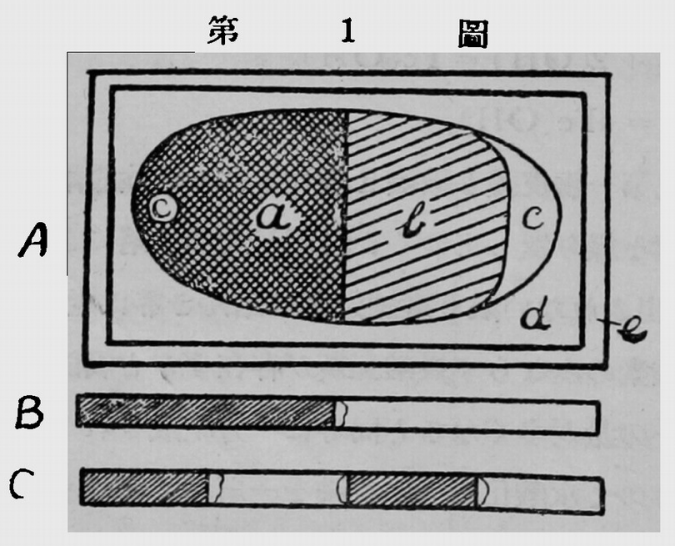

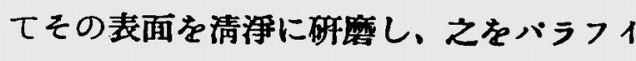
ンを塗布せろ厚板紙にに密接せしめ更に表 面を第 1 圆 (A) の如く 2 枚にまたがつて 棈圓形の鐵面をぬき出し、他の部分 $d$ は 全部バラフィンを以て鄅ひ、棈圓形の牛分 $a$ には鐵錆を望つたま・篮布し $b, c$ の部 分は鐵面のま・之を $\frac{1}{10}$ 瓦モルの食城水中 に浸しておいた。又電解鐵を長さ 7 粧、幅 1 粴の試料を作つて之を清淨に研磨してか

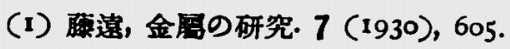




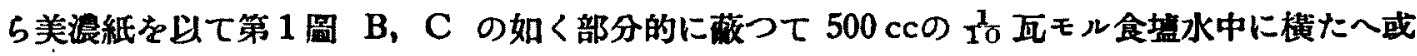
は立てかけて放置しておいた所、2 時間後には鐵錆面と鐵面又は紙をらて蔽つた個所と鐵面と の接細部より色づいてくろのね認めだ。えが事筫は紙面下の鐵と他の鐵面とで、或は錆の下面 の鐵と他の鐵面とで酸素の供給を異にし、鐵面に接近せる紙下の鐵或は錆の下面の鐵が陽堛 と

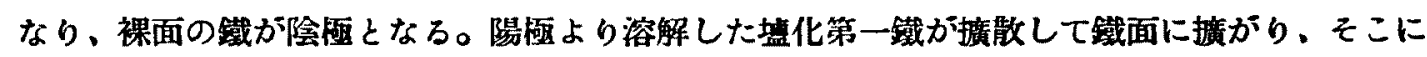
生成してるるアルカリに會つて水酸化鐵を生じ、酸素によつて更に酸化せられ水酸化第二践と なり沈洀するため、紙面又は錆面の近くから錆びてゆき溸次同樣な現象が進行して鐵面は水酸 化第二鐵によつて蔽はれてゆく事が分る。試料 $A$ に於ては水酸化鐵は境界線より撗がり 1 日

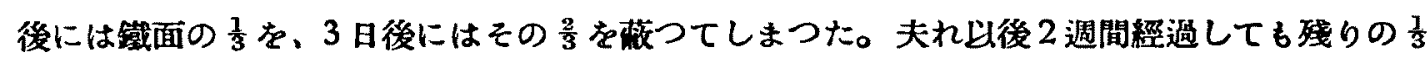
弱の所は稍々白色の薄膜によつて蔽はれて錆の面積は坦加しなかつた。だ白色被膜の上に少

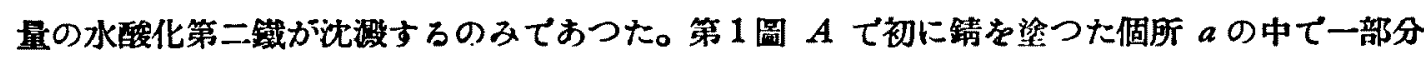
小さく鐵面を出しておいた所 $c$ も办白色被膜によつて蔽はれてるた。10日後にフェノールフ タレンを充分に滴下して數時間放置しておくと白色被膜の部分は赤色となつた。この事筫は明 かにそこにァルカッの生成を礁論せしめるるのである。この所は陰極となり、錆の下面は陽極 となつて腐蝕は長く進行するるのと考へられる。又試料 $B$ る器底に横へたるので $A$ と同樣 に鐵面は 2 週間後にその $\frac{3}{4}$ の面積を錆をるつて蔽はれ、殘りの $\frac{1}{4}$ は白色被膜て蔽はれだ。然る に $B$ と同榜な $\mathrm{B}^{\prime}$ と $C$ は器中に立てかけておいたものでおるから、陽極で生成せられた盐

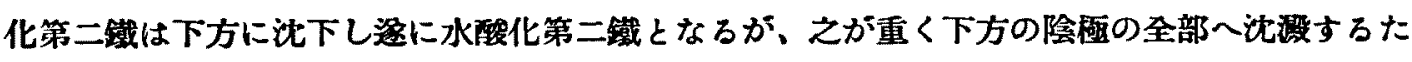
のに 3 日後には鐵面が全部靕となつてしまつた。之を取り出し、そのま・時計血に移して食盟 水とフェノールフタレンの混合液に浸せば、紙で包んだ方と反對の錆の沈㴛せる端の方が赤色 となつた。裏面を見ると紙に包んだ方は黑褐色になり、然らざる方は輝いたまっで、だ゙紙に 近い所が褐色に酸化せられてるた。双亟めて興味のある事は厚みの面をみると、紙に包んだ方 は一漛に孔（pits）を生じてるたが鐵面の方は紙に近い万の方の所まではゃ・一漛に孔を生じ て、下部の $\frac{1}{3}$ の長さの間は少しも生じてるなかつた。この事賽る办下部にアルカりを多く生じ、 後に其の上に沈溉した錆の影箱を蒙ることなく院極となつてるた事を示するのである。斯く赤 錆は日本紙と同樣隔膜の役目をするものである。

故に赤靕が一點でも鐵面上に存在すればその下面の鐵が陽極となり易く溶解酸素の浱淡電池 形成を容易ならしめる。斯榜に赤錆の存在は栍面上にある小さい穴ピット（pits）と同じ役目 をするもので腐蝕初期に於ける腐玲速度の促進作用をなす原因となる。

（C）大氮中に於ける赤錆の登生及び濕度と赤錆との關係

今同じ材料で出來てるろ鐵片を2枚取つて來てその表面をよく研磨して鏡の檍にしたとする、 
その一方を日本の樣な登度の多い所へ、他方を乾燥した所例へば何虎が少漠の栐な所へおいて 長い期間放つておいたとすると、日本の㨾な所では直ちに鐵面に赤錆を生ずるが乾燥した所で は錆び難くその光澤も失はれない、之は溔氣が多い所で赤錆が出來易い事を示す事實である。 滋氣が存在しなければ上述の赤錆發生の機構から考へて當然の事柄でら。しかし濕氯がいく ら多く存在してるても之が鐵面に凝集して水滴を生じなければ錆は出來ない。即ち鐵面が露點 に達する事が必要で、大氣中の㬎度と温度とに大なる關係がある事が知れる。

以上は單に大氣中に於て鐵に作用するものが酸素と濕氣だけしか存在しないと云ふ理想的の 條件で物語つたものであろが、今若し大氣中に亞硫酸瓦斯や硫化水素の如きものが存在すれば

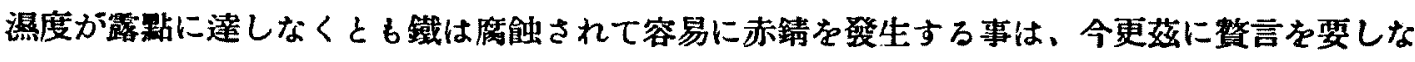
い。故に同じ日本に於ける同一地方でも工゙業地帶に於ける塲合と清淨な空氣を呼吸し得る郊外 とに於て同一鐵面に赤錆發生の速度にも大差のおて事は上記の事實から判斷する事が出來ろ。 及上記の如く特種な腐蝕性瓦斯が存在しなくとも大氣中に吸溔性の浮游固體微粒子が存在して るても亦大氣の濕度が能和に達しなくとも、是等微粒子が鐵面に沈知すれば赤錆發生の原因と なる事る考へ得られる事て、この點から考へても都會地の大氣が田園の大篓に比して腐蝕性の

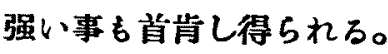

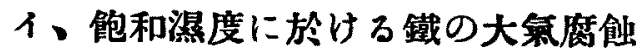

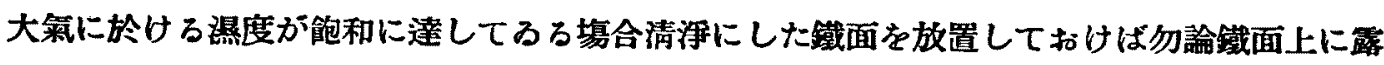
を結ひ腐蝕が始まる譯であろが、この水滴は純粋なるものであろから鐵面に援つて皮膜を作つ てる傳導度が低いだめ錆の發生する迄には相當の時間を要する。之に反して若し鐵面上に磷め 赤錆が存してるると在し蝕を促進する事は水中に於け石赤錆の作用と同一効果を示して錆の發 生を速かならしめろ。最近 W. S. Patterson ${ }^{(2)}$ 氏は飽和登度の元て出來万錆の性質について 研究してるる。同氏の結果を略述すると沃の如くである。

先つ試料としては $0.18 \% \mathrm{C}$ の軟鋼と $1.25 \% \mathrm{C}$ の高炭素鋼を $\frac{1}{8}$ 吋の板又は棒状材料から取り 页吋の厚さのものにした。啨が表面に喰ひ込んで入つてるろかも知れないのて、この痕跡 を除去する事が必要であつた。之は大篓中に曝した時局部腐創の原因となるからておる。其の

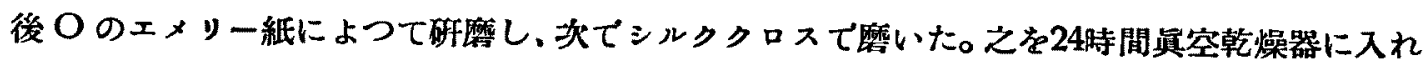
てから重量を湘定した。

是等の試片を硝子製タンク中に吊し、タンクの底に水を入れ上部は硝子板で蔽つた、このタ ンク內の滋度を露點に達しうろ樣に戸外に置いた。

(2) W. S. Patterson, Journ. Soc. Chem. Ind., 49 (1930), 203 T. 
苛性加里の溶液の上に懪露せしめた塲合 この管合にはタンクを苛性加里の溶液で洗滌して

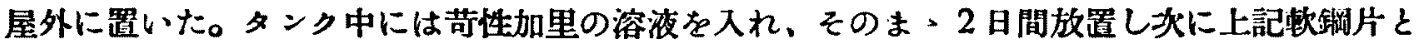
高炭素銅片を硝子鈎にかけて硝子杵に吊し、30日後に試料を出して、盐化カルシウムを入れた

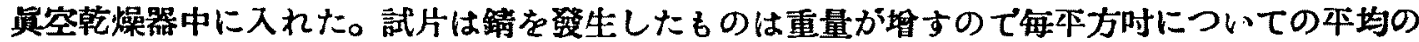

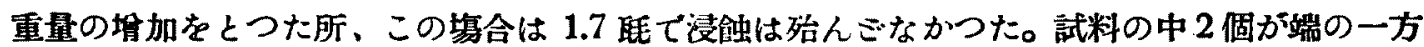
又は兩方に局部的に虽かに錆びてろろ事が認められたっこの賽驗結果から結論出來ろ事は能和 狀態の元で清淨にした鐵面の錆じ始める事實は大氣中にあろ不純物と根本的に密接な關保があ る。是等の不純物は全部とまでは行かなくとも苛性加里によつて除去出來る。是等の不純物は 大氣中の污物て、亞硫酸瓦斯、硫化水素、炭酸瓦斯等である。この實駿で空氣中の固體浮游 物は全部除去しておつたので結果は軟銅も高炭素鎆も大體同じであつだ。

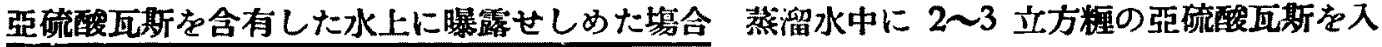
れたもの・上に試片を懪露せしめて 10 日間の本均垥量を見た所が每平方吋につき 32.1 毦で。 亞硫酸瓦斯の痕跡でもおると甚しく大氣を活性にする事が制る。

蒸溜水上に曝露せしめた場合 この賽驗も上記のものと同じに行つたが期間を長くした。水

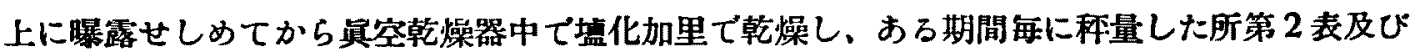
第 2 圖の如くであつた。

第 2 表

每本方时の增量（塊）

\begin{tabular}{|c|c|c|}
\hline 期 間 & 軟 铜 & 高孷素銅 \\
\hline 7 & 0.24 & 0.26 \\
\hline 25 & 4.28 & 2.48 \\
\hline 42 & 11.68 & 11.54 \\
\hline 57 & 17.68 & 18.84 \\
\hline 66 & 19.48 & 21.27 \\
\hline 85 & 23.08 & 27.07 \\
\hline 106 & 25.91 & 32.98 \\
\hline 127 & 30.64 & 37.25 \\
\hline 190 & 41.50 & 53.20 \\
\hline
\end{tabular}

第 2 圆

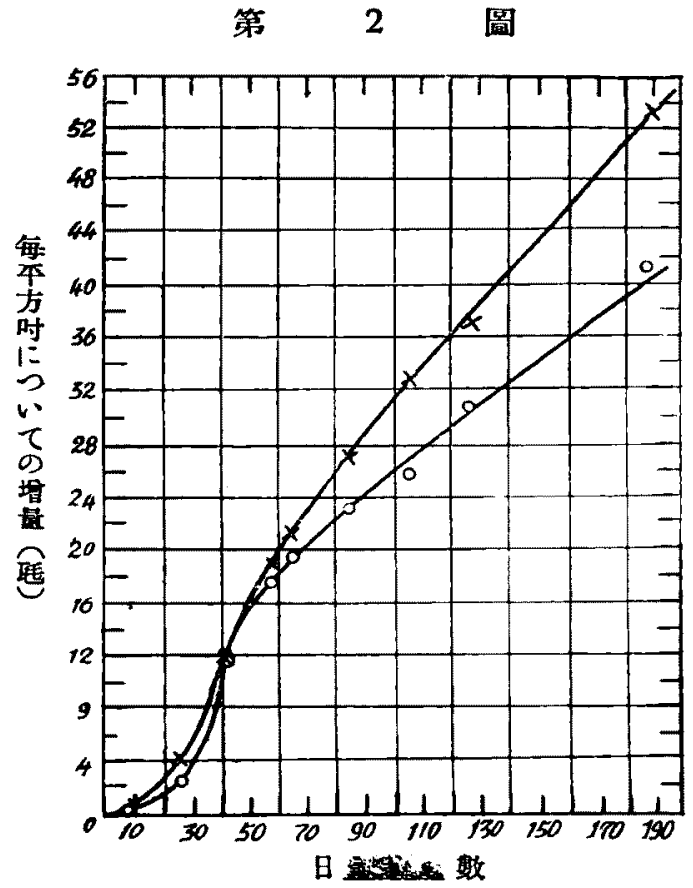

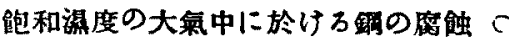

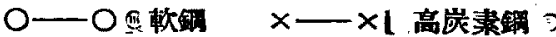


初めは腐蝕速度が悢慢であるが渐头にその速度を坦してくる。Vernon 氏が云へろ如く始め に凝集した水の皮膜が比较的純度が高いので之による浸蝕が相當に㳮いのである。所が靕が出 來るに從つて既迎せる所おる如く之が腐蝕を促進するので曲線は急激となる。この傾向は鐵面 が全部錆で蔽はれるまで繼䋻される。其の後になつて漏蝕速度は甚しく紱慢になるるのである が、本實駸の如く期間に限りある鹪合には即ち曲線が直線的に急激な触度で進んでるる㙋合に

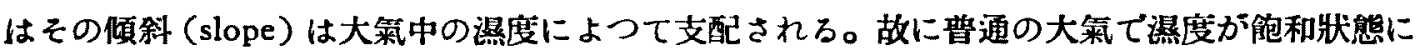
あろ告合に鐵の腐蝕進行過程に三階段がある。第一階程は大氣の純度或は㴡游污物の量の多少 によつて支配される浸玲開始の時であろ。第二階程は鐵が赤錆によつて漸次蔽はれてゆく所て 腐蝕淮行の最も激しい時、次の第三階程は鐵面が全部錆で蔽はれて大氣中の濕度が重大因子と して働く時の三階段ておろ。

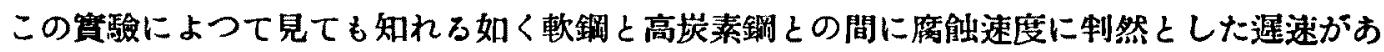
ろ、即ち鎆の方が鐵よりも一层早く錆びてゆく。之は大氣試驗に於で゙あろが普通中性溶液中 に於けろ腐蝕速度に及ぼす材筫成分の影秏は大いなる因子とはならないのであるか、酸による

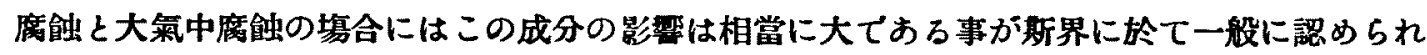

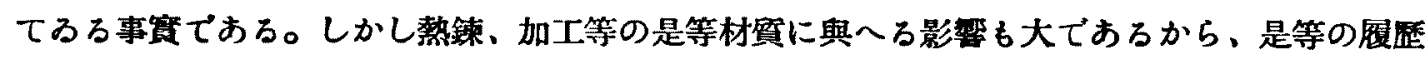
を等闑にして兩者の佣蝕速度を彼此云ふて之を一般に結論してしまふ事は間違である。

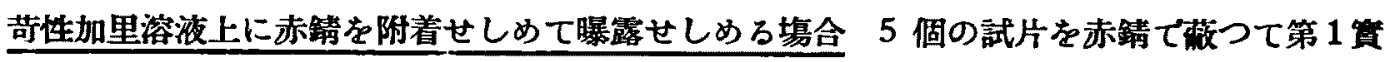
驗の如くして 50 日後の增量を見た所が每本方吋につき 33.2 聒であつた。赤錆をつけないもの は錆を生じなかつた。透つて一度でも錆て籍はれるる大策中から不純物を苛性加里で除去して る腐蝕を防止する事は出來ない事が制る。この第合腐蝕を支配するものは大氮中の不純物より も寧ろ發度によると考人られる。

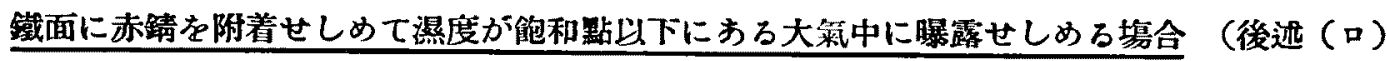
不䳌和温度に於けろ鐵の大氣中度蝕參照) 6 個の試片を本均の濕度 $59 \%$ と云ふ室內大氣中に曝 露せしのて 50 日後の平均增量を检べた所每本方时につき 2.16 毦あつた。勿論赤靕が附着せず

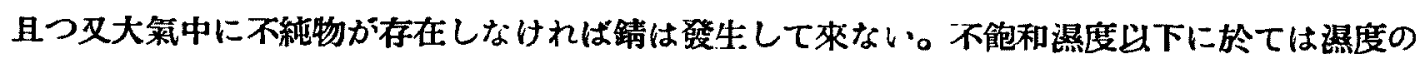
百分本が低くなると赤錆の腐蝕促進作用の速度を減退せしめろ。赤錆存在に於て淐度が何\%の 所から腐蝕を促進するものかその臨界愍度を劃然ときめろ事は困蜼であろ。何ぜなれば赤綪中

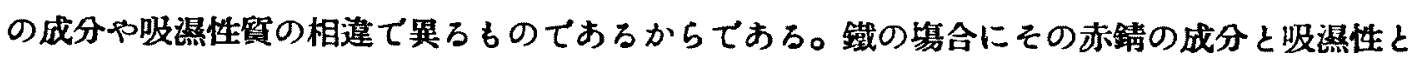
の關係について向ほ充分なる研究を必要とする。仍てこの研究者 Patterson 氏か Hebbs 氏と 協力してこの關係を相當に明かにしてるるからえについて後迅する所がある。

大氣中に於けろ腐蝕鐵の狀況 偣通の大氣中に於て鐵鋼が錆び始めるには大氣中に不純物が 或量含有されてるら事が多くの第合に原因となろものて、濕度が相當に高く或は吸望性の固铻 
微粒子のために鐵面上に局部的の腐蝕を起す。軟銅の錆び始めたものを見ろと無數の小斑點を 中心として腐蝕が起つてこ・から擴り逐に緛いた細い不規則的な線狀にまて發達してるろのが 見られる。台ほ時間が經過すると線狀の間の部分が錆で敕はれる樣になる。部分的に隔離され てるた小斑點から發生する錆の發達する事情を少しく精しく檢べろとフェライトが陽極的浸蝕 を受けてるろ事、及是等の中心點から細い線に沿ふて腐蝕が發達してるる事から考人て上記扄 蝕の進行が永縝してるる事を示すものである。然るに電解鐵の樣な純鐵は腐蝕初期の牀況は上

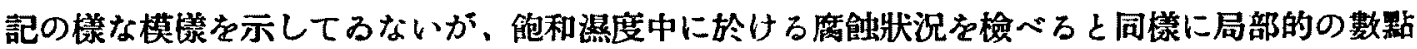
から始まり、各點が之を心として擴大してるる樣子が見られる。銅の埸合にてその中セメン

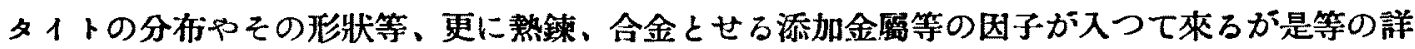
細については重要なものであろが茲には省略しでく。兔に㑇鐵銅面が錆によつて部分的に蔽 はれ腐蝕速度が增大され全面が錆で被灭されてしまへは速度は大呺貫一定となつてしまふ。この 理由については轧遮せる通りで赤靕の下面が陽極となつて腐蝕は進行し、漸次その速度が聕大 して曲線が急激に傾くのは腐蝕偶 (Corrosion cells) の数が澤山に坦加して之が作用し出すか らであると述べていた。こして全面が錆で蔽はれた時に腐蝕の速度の促進は止り、外部の條件 がそのま・につょく限り一定となろ、特に㬎度が一定ならば速度は甚しく娍退して一定となつ てしまふ。

\section{口、不飽和滋度に於ける鐵の大氛腐蝕}

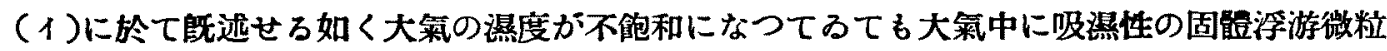
子が存在するか久は鐵面上に赤錆が附着してろれば瞔は腐蝕されてゅくるのであろ。吸濕性微 粒子の事については前迅の Patterson 氏の研究結果で制明してろるが赤錆の作用について不䳌 和望度との關係を更に一居精しく研究してみなければならない。所が幸ひ最近 Vernon ${ }^{(3)}$ 氏が 次の如き條件につきこの間の關係た明かにしてるろからその結果について說明してみよう。即 ち期閒 W とは11月乃至 4 月の季節で露點と最低温度との差が $12^{\circ} \mathrm{C}\left(22^{\circ} \mathrm{F}\right)$ にもなつて發度

\begin{tabular}{|c|c|c|}
\hline 件 & $\begin{array}{c}\text { 期間 } \\
(5 \text { 月 }\end{array}$ & $\left(\begin{array}{c}\text { 期間 } W \\
(1 \text { 月 }\end{array}\right.$ \\
\hline 平均温度 & $64^{\circ} \mathrm{F}$ & $67^{\circ} \mathrm{F}$ \\
\hline 本均相對然度 & $68 \%$ & $43 \%$ \\
\hline 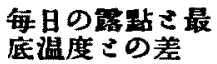 & $8^{\circ} \mathrm{F}$ & $22^{\circ} \mathrm{F}$ \\
\hline
\end{tabular}
としては低い方である。斯榆な條件に於て清棌な 鐵面を大策中に曝露せしめた所錆が不能結的に登 生した、そしてこの靕は鐵面で圍繞されてるた、 但し W 期間の最後になつて鐵の全面は赤錆て蔽 はれてるた。斯の如く簬點以上比烄的に乾燥して るたにも拘はらず錆を發生した譯は明かに大氧が 
空氣と水葬氣のみでなく複雜したもので吸濕性浮游固體微粒子が存在してわたものと考へなけ ればならない。是等の微粒子は都會地の大氣中では酸性物質を吸着して多くは酸性になつてる ろ、故に是等の微䊀子が清浮な鐵面に沈淔すればこの部分から錆が發生する。隨つて湿度が露 點以下に於ても錆の發生は起りうる譯て、この事實については前項（1）に於ても當然起りう ろ事をだ既还した所がある。本項に於てはVernon 氏がえを證明した筫驗を記述して更に 之を確めてみよう。今 2 個の鐵片をよく研磨して各々硝子管に入れ、一方は純綿毛で空氣を憈 過し室温でその空氣を同じ速度て硝子管中を通した所第 3 圖の如くで 7 日間空氣を 100 立方呎

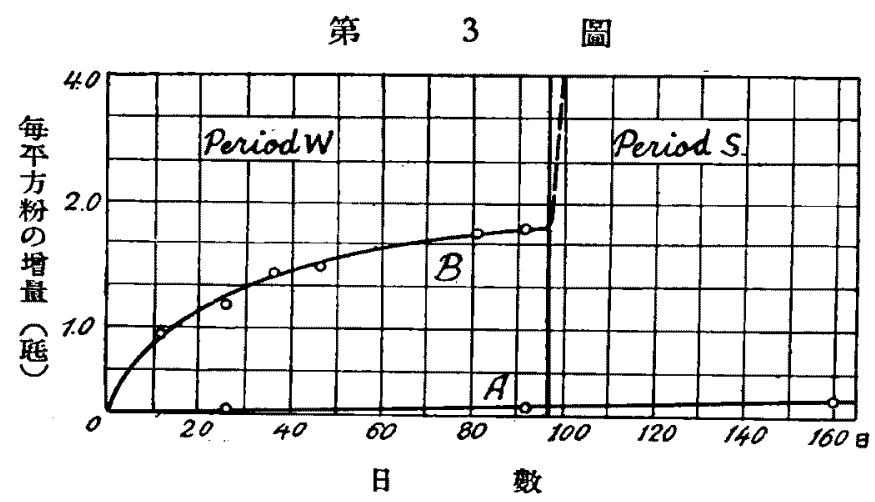

$A$ 鐵片れモスリンターデ (Muslin Cage) で包んげ㘯合

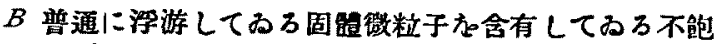

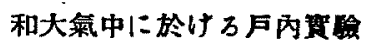

通して止めた、瀘過空氣を通し た塲合は鐵面は完全に輝いてる たが他方のものは僅かに、しか し必ず錆を生じてるた。この錆 は全面に斑點となつて隔離され てるた。この方法は硝子管を通 る空氣の流動のために鐵面にそ の粒子を沈澱せしゅろ䄾會を少 くする不利がある。仍て同一材 料のものを同時に懪簬する粶に 3 個の試片を夫々モスリンター ヂ (Muslin Cage) の中に入れ數时おきに置いて重量測定の時のみこのクーヂをあける漛にし て實驗した所、モスッンで包んた試片は全く錆を發生しなかつた。期間 W の終りまで始めと 全く同一であつたが、モスッンで包まなかつたものは既に上述の如く全面錆びてわた。この腐 蝕の曲線についての說明であるが、始めは全面が腐蝕される樣に暴露してるるので初期に於て

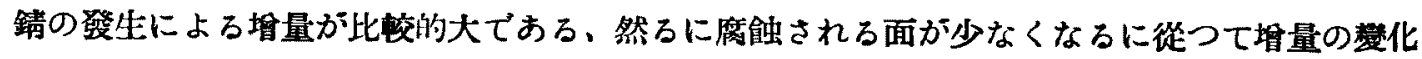
が漸次に遲くなる。

炏に大氮に於け万温度が能和に達し浮游固體微粒子の存在せぬ塲合に於け万鐵錆の發生につ いて上記 Patterson 氏と等しき研究を行つた。即ち2 呎本方の木染に試料を吊してモスリンで 包及是等を大きく陶器製の槽中に入れ、その底に水をたっへ、モスッンの下部をこの水の中に 漬けた、槽の上部を全部硝子板に蔽つて人工的に加熱し温度の篎化を調節して露がたまる樣に した。16固の試片の中 2 個を每週取り出し他の 2 個で置きかた。第 4 圖は 8 週間の曝露によ つて篔量した本均の全堆量を示したものである。第 3 圖の曲線とその傾向を異にしてろる。之 は大氣中に浮游微粒子がないので初期に於ける腐玲は比較的に遲い、しかし後になると速にな 万譯は水分の皮膜が存在し局部電池の作用が起る、この水分の比较的純粹なる事が促進速度を 
第 4 圖

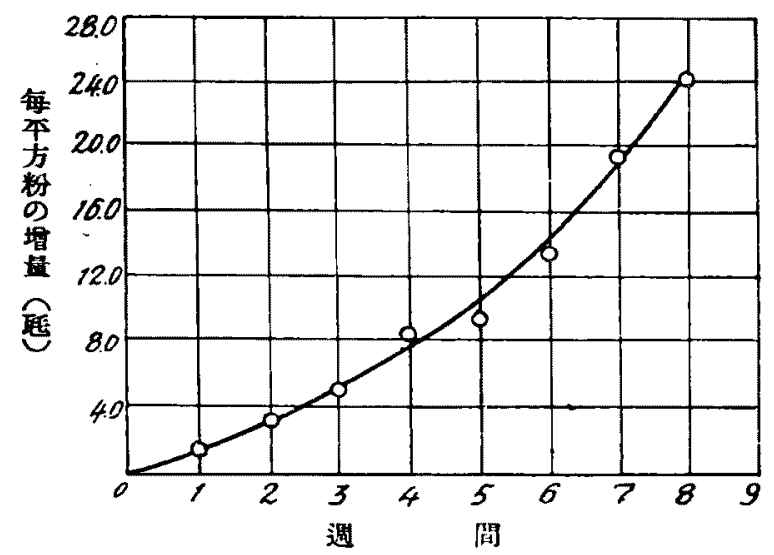

浮游固解徽粒于の存在しない高望度大氣中

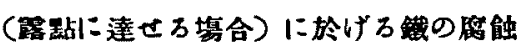

䌅める、しかし靕が出來てくらに從つ て局部電池の數を坦しその作用が激し くなろので時間が經つにつれて谷々促 進せらろ。全部錆で蔽はれると再び遲 くなろ譯であろが、この賽驗は 8 週間 のみでこれまてしか曲線が播かれてる ない。

次に湿度が比較的に高い室內の大氣 中に於けろ腐蝕の研究として、5月〜9 月䜤び㬎度 $68 \%$ 、平均温度 $64^{\circ} \mathrm{F}$, 期 間 W $43 \%$ 㬎度に比して㬎度高く、 浮游固體微粒子は全量に於て逶に少く

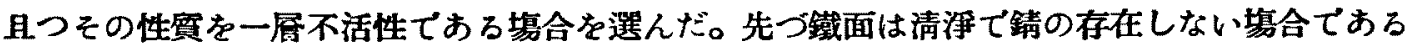
がこの塲合は前二者の中間におろ、即ち大氣の相對濕度之活性の固體微粒子の含有量が兩者の

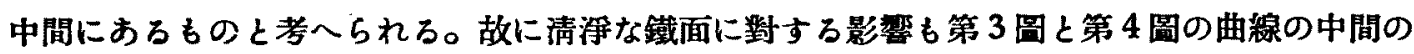
型をとろるのと考へられる、一季節の嫩察を行つた所曲線は樅軸に僅にコンターブしてるろが 他の部分では第 3 圖の如くコンべックスになつてるろ。しかし浸蝕の强さは $\mathrm{W}$ 期間の間の牛

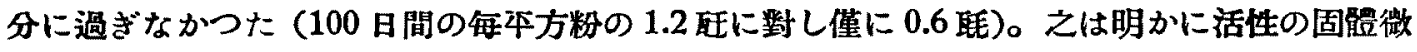

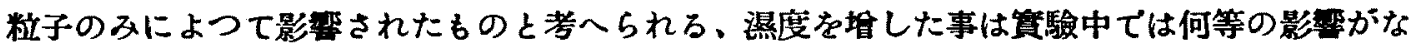
かつた事が制る。

次に急々本論に入つて乾いた錆が鐵面に附着してるた堭合について賽驗してみた所、浮游固

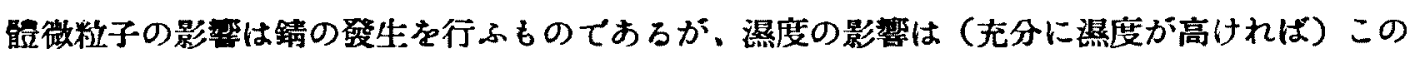
初めの浸蝕を促進せしめろために必要なだけの水分を供給する事となる。この促進作用は驖錆 のあろ點に於て之に隣ろ部分の鐵、水分、酸素、錆が一緒になつて作用するので是等によつて

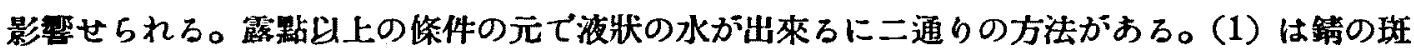
點が吸㬎性である事、この錆の斑點は固體微粒子によつて出來たとしても又始めから附着して 乃たものてもかまはない。(2) 大氣中の水蒸氣の溽度が增加して臨界㬎度に達する事、この二

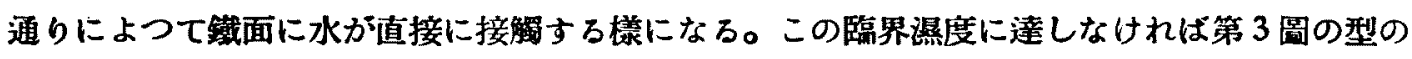

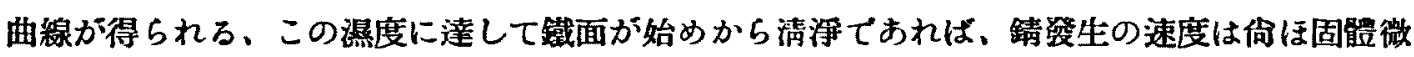

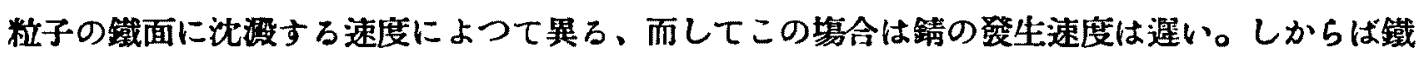
面が既に錆て蔽はれて臨界濕度に達したと云ふ樣な㙏合はこうなるか。第 3 圖て W 期間か $\mathrm{S}$

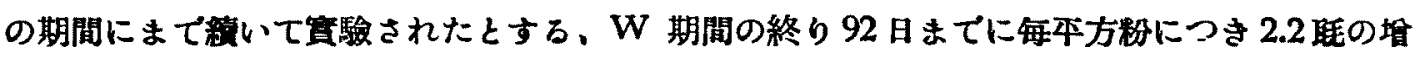


量があつた。それり上67日經過させて試驗してみた、67日前の所では測定しなかつたが67日後 のものは每平方粉につき 48.5 毦と云ふ極めて大きな堦量を示した。この結果は諴に興味あるる

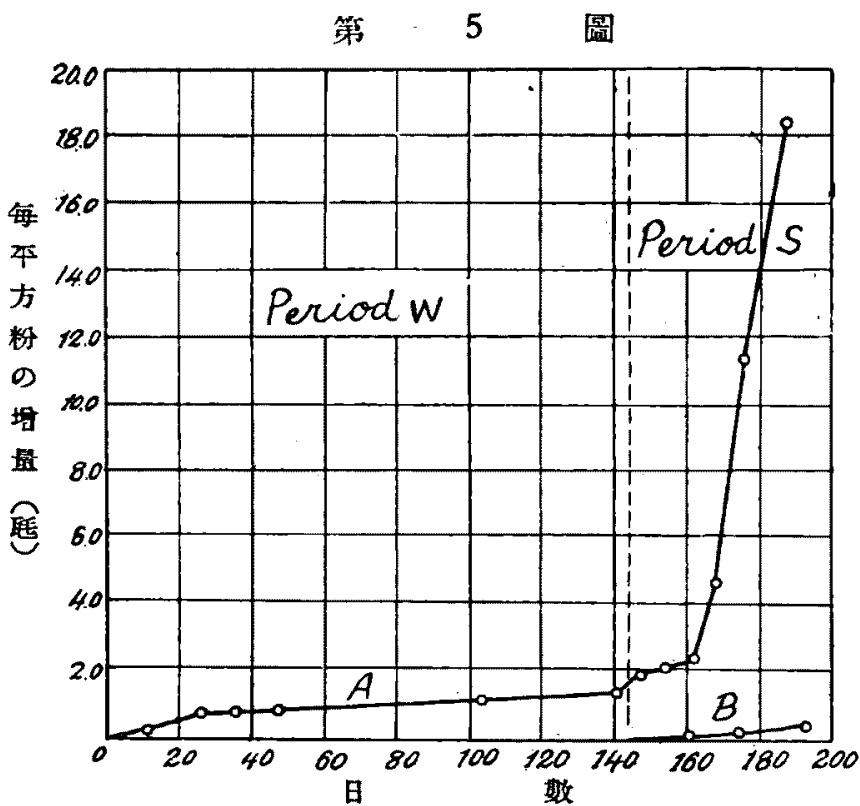

$A$ 比較的乾煤せ万大或 (Period W) 中で既に錆か生

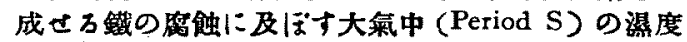
增加の影答

$B$ 研紮清淨にさろ鐵面に及に゙す濕度㙕加の影響
のて゚、W 期間から S 期間まで の變化した狀況を系統的に检べ た所第 5 圖の $A$ の如き曲線が 得られた。43\%の哭度か $568 \%$ に㙁加した所で影慗が著しく表 はれる。一方錆の附着してるな い試料について行つた結果の曲 線は第 5 圖 $B$ の如く小さくお つた。

この事實について研究者の Vernon 氏は何等說明を興へて るないが後述の如く Pattersen 氏は鐵錆の物理的條件がの臨 界點に達して少しく水分か坦加 され著しく變化するものである と詋明した。

夾に浮游固體微粓子の存在しない大氣中に鐵を曝露せしめて生成した眼に見へない位の極め

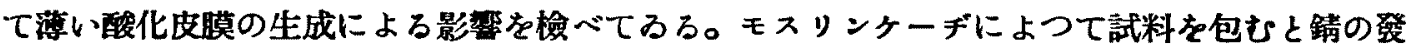
生を防止する事は既迅した通りであるが、期間 W 中で斯樣な方法で試料を懪露せしのたもの

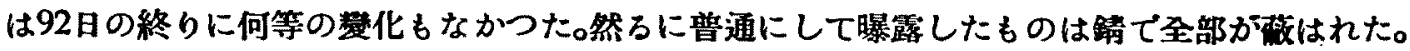

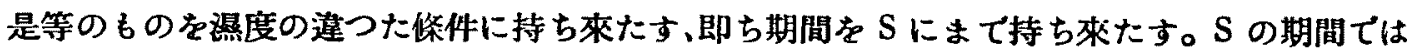
锖のあろものに對しては極めて大なる影鄉を與へろが錆のない清淨なるのにはその影䨋が基し く小でおつた。鬼に角上記のものを S 期間に持ち來たすとモスリンで包んだるのに對しては份 ほ眼に見へろ樣な影憵を與へなかつた。第 3 圖 $A$ の曲線を參照して知れる樣に重量的にも大

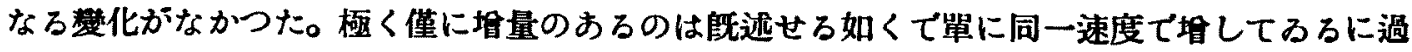
ぎない。159日間の全增量は每本方粉につき 0.2 的に過ぎなかつた。一方モスッンで包まない ものは 48.5 㘪の堭量で甚しく大でおつた。モスッンで包んだ試料を 314 日目に見ても未だ何

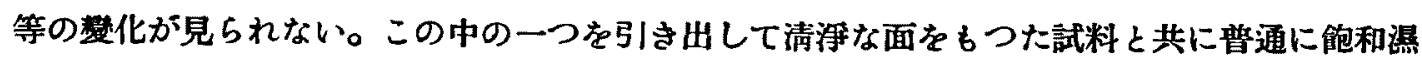
度の大氣中（浮游微粒子の存在しない）に曝露せしのた所、古い試片は未だその光を保つて乃 たが新しいものは錆が登生して來た。其の後になつて小さい錆の斑點た示したが、其の後の津 


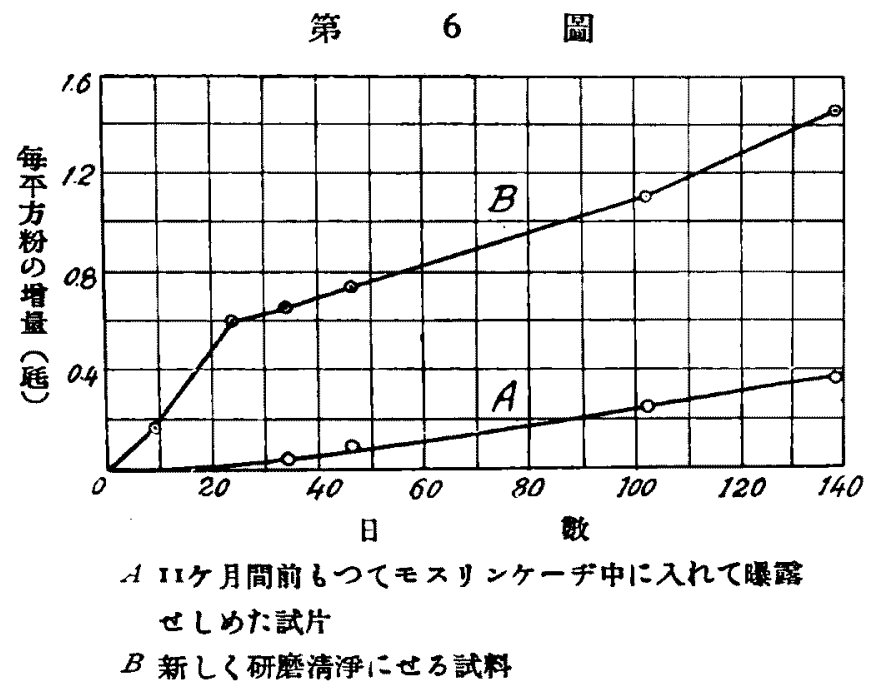

蝕の進行模樣は他の㙁合に見ら れるものと全く異つて新しい辂 面に出來てるろ錆の斑點よりる 一屡激しく哚くなつてるた。第 6 圖の垍量から見万と前もつて モスッン中に 314 日間曝露せし めたもの - 浸蝕速度は $A$ の如 くであろが、えに反して新しい 普通に晎露したものは $B$ の如 くであろ。二つの曲線が縱軸に 比㬵的に大なる差異奔示す事は 明かにモスリンで包んで前ちつ て曝露せしめたもの>表面に保護皮膜が生成された・めである事が知れる。 八、赤錆中の水分こ㸛界濕度の關係

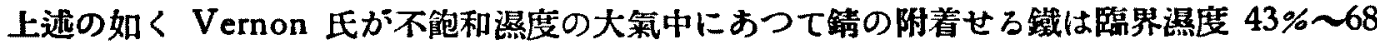
\%に達して始めて腐蝕が促進される事を觀察した。仍てこの事貫を說明せんと Hudson ${ }^{(4)}$ 氏 は鐵錆を色々の㬎度におき、この臨界點に於て吸登性とならのではなかな確めんとした、こ の研究結果は期に反して何等の特暴な答化が認められなかつた。 Vernon 氏はこの Hudson 氏によつて使用された錆が既に賽驗前にこの臨界濕度を通つたものた用ひたのであらう、その ためにこの點で特異性が認められなかつたのであると云ふてるろ。然ろに最近前記の Patterson と Hebbs ${ }^{(6)}$ の雨氏は、先にVernon 氏の結果を何等臨界㬎度又はそれ上上で錆が吸㬎 性であると考へろ必要はない、慥つて Hudson 氏の筫驗結果の如くこの臨界範圈で錆が急に 重くなると考人ろ必要はなく、賽際この範圍內で錆が大なる重量の㘿加を示さない事を筫驗て 確めた。更に鐵錆は常に 50〜20\% の水分を保持してるるもので、濕度0\%の條件にした所に 長らく放置しておいてもこの位の水分は保存されてるる。不 0 〜 $100 \%$ の濕度の大氣を通すを

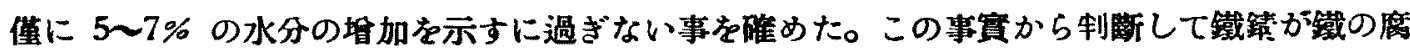

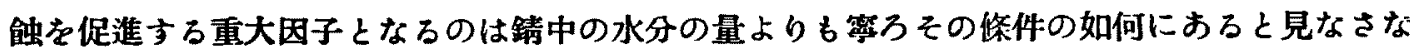

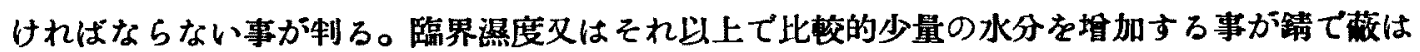
れた鐵面か臨界望度以上に保たれた境合に腐蝕速度に大なる垥大促進作用をなすと認めろ事は

(4) Hudson, Trans. Faraday Soc., 25 (1929), 240. (5) W. S. Patterson and L. Hebbs, Trans. Faraday Soc, 27 (1931), 277 . 
困難である。少し許りの水分の剒加と云ふ分量だけで斯く急激な腐蝕促進をなすとは筫際にも 考へられない。然るに今鐵の赤錆がゲル狀の組䢂をなしてるると考へれば、少量の水分の垥加

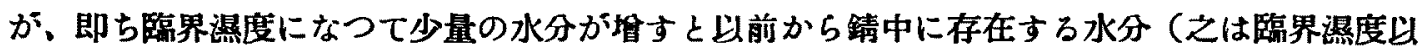
下に於ても保持されてるる）と一緹になつて多量の水分が腐蝕促進に役立つるのと說明つける 事が出來るのであらうと云ふ、之が Vernon 氏の砰究結果を說明する Patterson と Hebbs 兩氏の論旨である。仍で今兩氏の呼究の詳細を記远してみると次の如くでおろ。

$0.18 \% \mathrm{C}$ の軟鋼から赤錆を作つた、軟鋼綠で試料を木枠に吊し大氣中にして生成された鐵錆 を及のない器具でこすり落した、試料としては次の 5 種を選んだ。

錆 I ロンドンの Clerkenwell の屋外に2ケ月間放置して得だの。

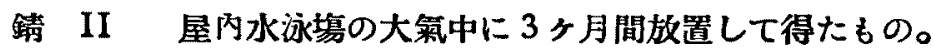

錆 IIII と同じ。

錆 IVIと同じであるが放置期間を長くして得たもの。

鍮 V II と同じであるが放置期間を長くして得たるの。

使用した鐵錆の量は $0.68 〜 0.97$ 瓦で、15 ccの科量瓶を用ひた。錆を各瓶の底に薄く摭げ是 等を前通の硝子憋乾燥器中に入れた。乾燥器の下部には浱硫酸を入れ所要の温度とした。是等 を全部 $20^{\circ} \mathrm{C}$ の恒温慒に入れ蓋の所は上に出しておいたが出來ろだけ深く入れた。蓋の所は $20^{\circ} \mathrm{C}$ にならないので疑集した水滴が科量瓶中に入 ら㥬に V 字型の酸を蓋と瓶との間に入

第 4 表 一定滋度に於けろ重量の禁化

\begin{tabular}{|c|c|c|c|}
\hline 曝露時間 & $\begin{array}{l}\text { 㰌外錆全堛 } \\
\text { 量 (毝) }\end{array}$ & 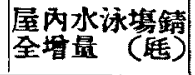 & 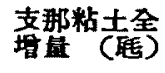 \\
\hline 54 & 24.4 & 57.5 & 12.9 \\
\hline 84 & 24.0 & 57.0 & 10.9 \\
\hline 108 & 21.4 & 57.7 & 11.9 \\
\hline 132 & 25.4 & 60.0 & 14.5 \\
\hline 156 & 24.4 & 58.5 & 12.5 \\
\hline 175 & 23.4 & 56.5 & 10.0 \\
\hline 226 & 24.6 & 59.3 & 13.5 \\
\hline 245 & $24 \cdot 2$ & 58.1 & 11.5 \\
\hline
\end{tabular}

れた。蓋が室溫に出てろろ所が相當に大で

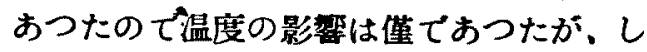
がし V 字型の潄を入れたので隔壁となり この影阷は極めて小さいものとなつた。そ の結果は第 4 表の如くで、赤錆の二つの試 料について得られたもの及び支那粘土をフ ランクテストにして測定したものである。 三つの試料について得られた埥量に偏差か 見られるが皆同一傾向で本行曲線を示して 乃ろので、この㾫差は鉤の生成塲所に關倸 があろ事が制る。錆（の試料を望度を溸次 曾し各々 48 時間一定に保つた、その結果は第 5 表と第 7 圖に示すが如くである。試料を 90〜 $100^{\circ} \mathrm{C}$ の湯槽上に 12 時間おいたが乾燥狀態 ( $0 \%$ の烝度の重量) の重量で $0.9 \%$ 上內ててれ 以上乾燥する事が困難であつた。其の後 $105^{\circ} \mathrm{C}$ で空氣浴中で 10 時間乾燥な行つて始めの乾 燥狀態に於けろ重量より $0.1 \%$ 下の値を得た。試料を 12 特間鴒和狀態においた所重量は始め 


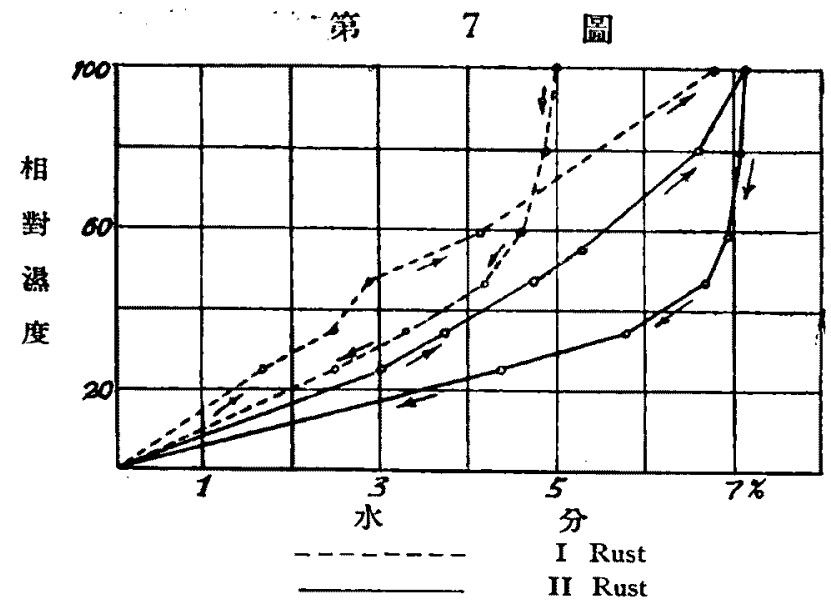

の重量と殆んご雃りなかつたが、 1 週間の終りに僅に $4.98 \%$ の全重 量の坦加がおつたのみであつた。 前もつて上記の如く加熱したもの は 6.76\%の算加があつた。夷に滋 度を降下してゆき各瀑度に96時間 おいた塲合に減量を示した、その 結果は第 5 表の如くである。

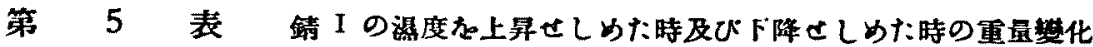

\begin{tabular}{|c|c|c|c|c|c|c|c|}
\hline 淘 度 $(\%)$ & $\circ$ & 25 & 35 & 47 & 59 & 80 & 100 \\
\hline 全增 竓) & - & 16 & 24 & 28 & 40 & - & 66 \\
\hline 全 堵 蛋 $(\%)$ & - & I. 64 & 246 & 2.87 & 4.10 & - & 6.76 \\
\hline 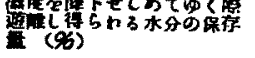 & $\circ$ & 2.46 & 3.28 & 4.17 & 4.56 & 4.82 & 4.98 \\
\hline
\end{tabular}

錆 III を空氣浴槽中で乾燥して一定の重量となし初めに濕度を漸次垥して空氣中においてお く、次に又淐度を漸次降下せしめてりくとその堽減量は第 6 表と第 7 圖の實線の曲線で示す如 くになる。

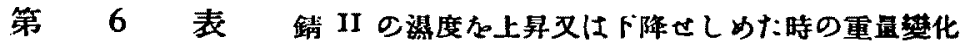

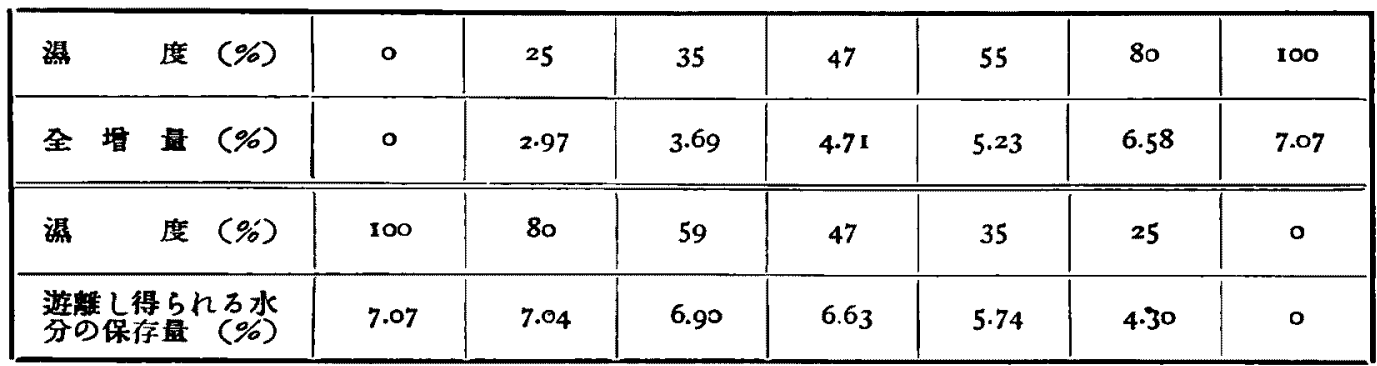

この曲線の型と $105^{\circ} \mathrm{C}$ に乾したンめ水分に對する容量 (Capacity) の少くなら事から制䰜 して次の事が知れる、即ち臨界温度に相當する赤錆中の水分の條件を決定するには鐔は鐵面か ら除去されたら直ちに使用されなければならない、そして初めに能和狀態に曝管せしめてから 漸次渠度老降下してゆく事が肝要である。故に第7圖の破線で描き水分を增してゆく曲線では。 一度 $105^{\circ} \mathrm{C}$ に燒いた錆を使用したので驖面から除去して直ちに使用したものとは條件が異つ 
てるろ、鐵面から除去したものは不能和㬎度中で少くとも一回位は能和に近い泚度となつたも のが多く、第 7 圖の實線で描いたルーブに近い履歷を少くとも一回は繰り返したものであると

第 7 表

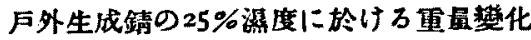

\begin{tabular}{|c|c|c|c|}
\hline 時間 & 重量(䣶) & 時 間 & 重国 (㣰) \\
\hline 24 & 702.5 & 192 & 698.5 \\
\hline $4^{8}$ & 699.9 & 214 & 698.5 \\
\hline 67 & 699.1 & 235 & 698.5 \\
\hline 120 & 698.0 & 264 & 698.3 \\
\hline 144 & 698.0 & 288 & 698.3 \\
\hline 168 & $69^{8.3}$ & & \\
\hline
\end{tabular}

考へられる。隨つて破線 $(\rightarrow)$ で示した曲 線だけを見て結論と撞著すると考へてはい けない。呼究者も云つてるる通り水分だけ で詋明はつかないのであるからである。

第 7 表は室外生成錆の一種を25\%の温度 中におき本衡に達するまでの大解 9 時間を 示したものて、三つの屋外生成錆と水泳墇 內て得た靕について上記の如く飽和に達せ しめてから發度を漸次降下して行つた㙋合 の本均の減量は第 8 表、第 9 表及び第10表

に示す如くである。

第 8 表 䤻 III F外生成錆（短時間）

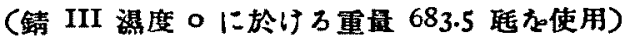

\begin{tabular}{|c|c|c|c|c|c|c|}
\hline 湨 度 $(\%)$ & 100 & 80 & 55 & 38 & 25 & $\circ$ \\
\hline 本衛に達するまでの時間 & 389 & 102 & 167 & 52 & 120 & $3^{13}$ \\
\hline 全 時 間 (潰まで) & $43 \mathrm{I}$ & 244 & 239 & 355 & 288 & 408 \\
\hline 重量の平均減量(恬) & - & 2.8 & 4.9 & 2.1 & 7.2 & 14.8 \\
\hline 最大倔差 + & 0.1 & 0.4 & 0.1 & 0.4 & 0.2 & 0.4 \\
\hline 最大 䏱 差 一 & 0.2 & 0.4 & 0.1 & 0.4 & 0.3 & 0.3 \\
\hline
\end{tabular}

第 9 表 F外生成錆 (長時間)

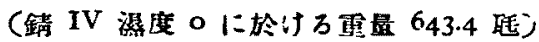

\begin{tabular}{|c|c|c|c|c|c|c|}
\hline 濕度 $(\%)$ & 100 & 82 & 55 & $3^{8}$ & 25 & $\circ$ \\
\hline 本行に達するまでの時間 & 247 & 102 & 141 & 162 & 120 & $3^{13}$ \\
\hline 全 時 間(测定まで) & 286 & $\mathbf{2 4 4}$ & 239 & 355 & 288 & 408 \\
\hline 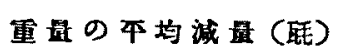 & -- & $x .7$ & 3.4 & 1.9 & 6.2 & 9.4 \\
\hline 最大偏 美 + & 0.2 & 0.5 & 0.9 & 0.6 & 0.4 & 0.7 \\
\hline 最 大 偏 差 - & 0.1 & 0.1 & 0.3 & 0.4 & $0 . \mathrm{r}$ & 0.2 \\
\hline
\end{tabular}


第 10 表 屋內水泳㙁生成錆

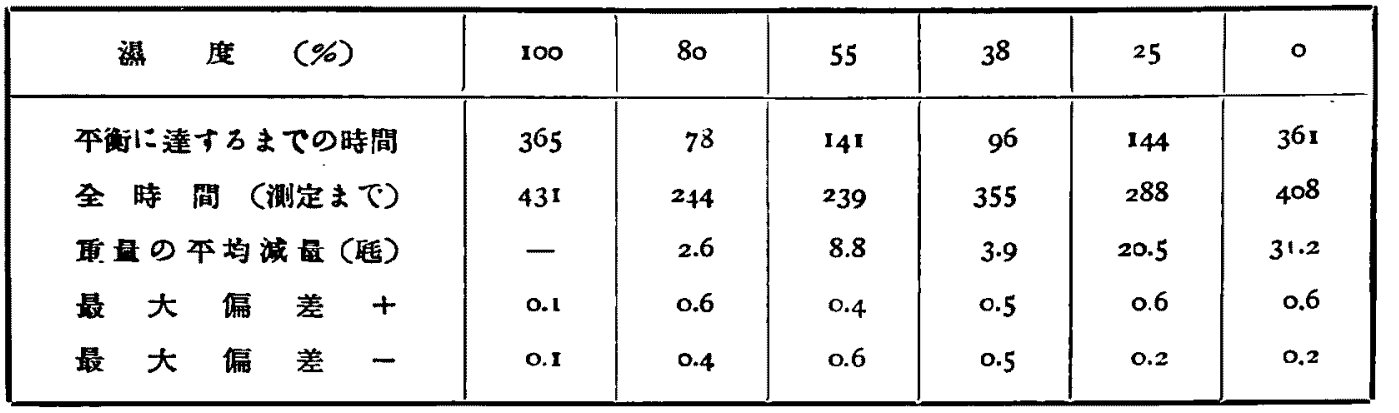

第 9 表に於けろ試料て 120 時問で平衡に達してから 120 時間から288時間の間に垥した量は

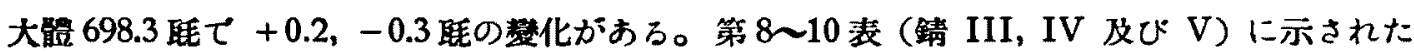
試料を次の如くに驗べた、即ち一部分を科量して先つ白金皿の中に入れて鈍赤色 (dull red

第 $\quad 1 \quad 1 \quad$ 表

瀑度。\%に於け万錆中の水分（計算）

\begin{tabular}{|c|c|c|c|}
\hline 輤 の 程 類 & 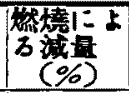 & $\begin{array}{l}\mathrm{Fe}_{2} \mathrm{O}_{3} \\
(\%)\end{array}$ & $\mathrm{Cl}_{2}$ \\
\hline 錆III 屋 外生 成 & 19.21 & $8 \mathrm{r.4}$ & - \\
\hline 锖 IV 屋外生成 & 15.01 & 85.37 & - \\
\hline 锖 $\mathrm{V}$ 屋內水永培生成 & 17.91 & 82.33 & 0.47 \\
\hline
\end{tabular}

heat）に加熟して最早重量の減少がないま でに一定とした、これには普通牛時間で目 的を達し得る。他の部分を硝酸に溶解し瀻 の量を测定し、若し㙉素がつてるたなら ばえをも測定した、その結果は第11表の如 くである。燃燒による淢量は $\mathrm{F}_{2} \mathrm{O}_{3}$ が $\mathrm{F}_{3} \mathrm{O}_{4}$ になる重量の減少をも含むものであるから

存在した水分の量は $100 \%$ から $\mathrm{Fe}_{2} \mathrm{O}_{3}$ (及びCl）の百分本の量を減じて出す事が必要である。 斯くして求めた値を第 8 表〜第10表に示された値と關聯せしめて㬎度によつて紗化する全水分 の量の化を第二酸化鐵の一分子中の水の 第 122 表 分子として出してみると第12表と第 8 㘣の 如くでおろ。曲線の型と濕度を上昇せしの てゆく塲合と下降せしめてゆく塲合で得ら れた値に著しいヒステレシスが認められ ろ、是等の事實から判断して赤錆がゲル狀 の組織をしてるるものておらうと考へられ ろ。斯くして求め得られた結果は先にVan Bemmelen $^{(6)}$ 氏によつて沈濞して得られた 鐵の水酸化物と㱠んミ同一である事が知れ

濕度な降下さしめてりく際に得た值 ( $\mathrm{Fe}_{2} \mathrm{O}_{3}$ I分于中の $\mathrm{H}_{2} \mathrm{O}$ 分于にしての全水分)

\begin{tabular}{|c|c|c|c|}
\hline 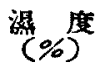 & 銿 III & 鐒 IV & 錆 $\mathrm{V}$ \\
\hline 180 & 2.54 & r. 89 & 2.61 \\
\hline 80 & 2.49 & ז. 86 & 2.58 \\
\hline 55 & 242 & 1.81 & $2.4^{8}$ \\
\hline 38 & 2.38 & 1.78 & 2.44 \\
\hline 25 & 2.27 & 1.68 & 2.21 \\
\hline$\circ$ & 2.03 & 1.53 & 1.86 \\
\hline
\end{tabular}

(6) Von Bemmelen, Zeits, anarg. Chem., 20 (1899), I 55. 


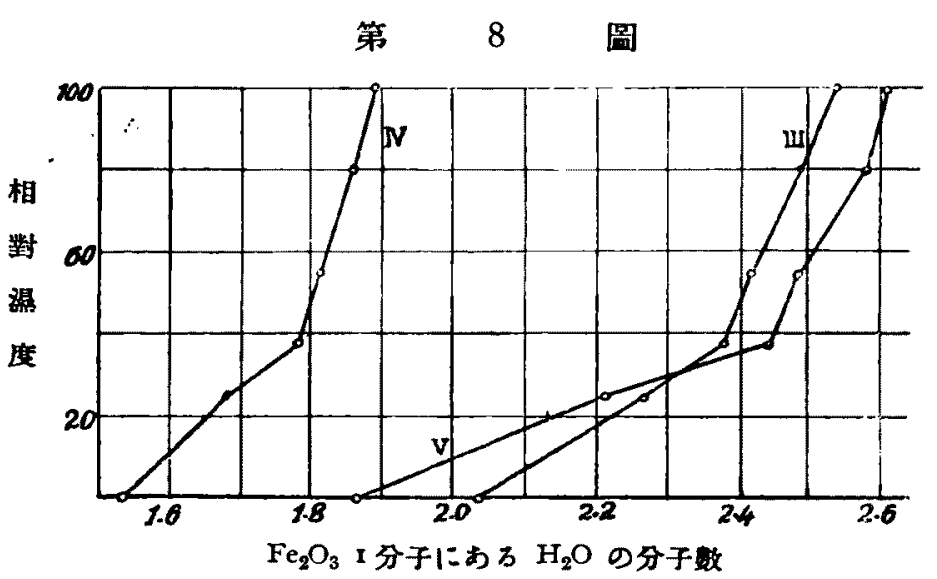

た。えがゲル狀である事は 水酸化鐵の色↔の上く知れ た性質から跑想出來るもの で元來水酸化鐵は沈澼より 作られ、又锖自身が沈政生 成物である事から考へても 當然に考へらるべき事であ ろ。この事實から出發して 上迅の結果は次の如く謨明 する事が出來る。それはゲ

ル狀組織についての珒酸について實驗した Zeigmondy(7) 氏の理論と Lord Kelvin 氏の毛細 管內の登氣壓の計算を基にして說明されようと云ふのである。

先づ望度を漸次降下せしめた時に得られた曲線を見る事とする。100\%から 40\%に下ると 锖から水分の比较的少量が失はれろ、この力法の間にゲルの毛細管中におろ水の外侧表面は水

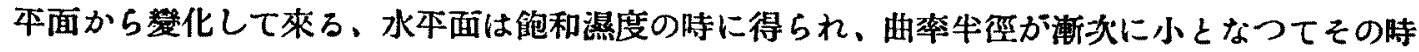
の濕度と本衡に達する。 $40 \%$ 位の所でこの際出來る毛細管の直徑に相當して毛管中の水の表 面がある曲率牛弳を描く、そしてこの牛徑は艮も小さい、そ以下の曲率牛徑は得られない。隨

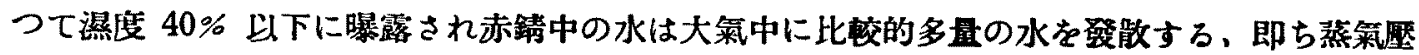
の一居大なる场合より多量に發政する、何ぜなればこのダル中の毛細管中の水分 (free water) に對する最小蒸氣㻺に達してしまつたのであから自由に遊雒しうろ水分は錆の中には最早残 留してるろ譯に行かないからである。何ほ錆の中に殘る水分は自由に出得るものてはなくゲル の表面及び毛細管の壁に强く吸着されてるるものである。この水分の大部分のものは明に强く 吸着されてるろので濃硫酸中に乾燥した位では赤錆から除去する事は出來ない。この水分は著 しく强いカでゲル中に保持されてるろに荤いないから缹度 40\% 以下に於て互に壓縮された狀 態 (state of mutual compression) になつて水分は殘留される。この水分か鄁萧として或は液 體として存在してるたにしろ腐蝕促進に歌與するものではない、即ち腐蝕作用には役立たない

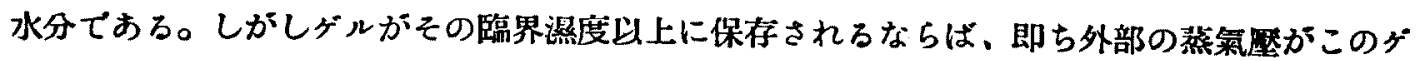

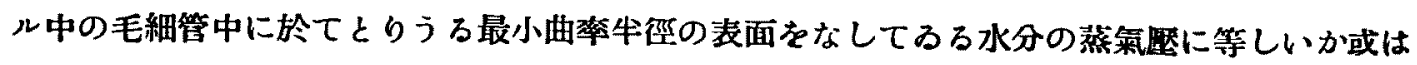
それら上にある時は是等のゲル中にある毛細管は水によつて满たされる。溰度が高ければ高い ほミ゙の水面は水本面に近くなる、毛細管が遊離し得る水で滿たされる時にはゲルは最早厘縮 
狀態にはなつてるない，故に吸着水は最早强く毛管中に保持されない樣になる。隨つて臨界濕 度に於て赤錆中にあろ水分が（始めに 15〜20\% 存在してるろ）極めて僅かに㘿加されるに過 ぎないにも拘はらずこの少量の水分の凔加が腐蝕促進に役立つ譯がよく了解される。即ち先に

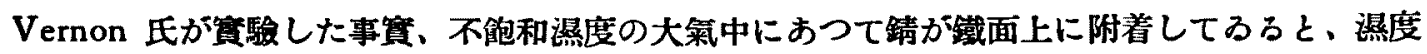
か臨界點に達して急激に腐蝕が促進される事貫を之てよく說明する事が出來た譯である。

\section{ミIII. 黑錆と大氞中に於ける防玲作用}

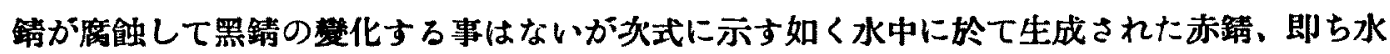
酸化第二緎が瀻面近くに於て生成される水酸化第一鐵と作用して所謂黑色の四三酸化鐵を生成 する事は考人得られる。斯く水中に於けるこの四三酸化鐵は一般に粒状に出來て緻密に出來な いために赤錆の如く酸素の擴散を防止する効果少く、赤錆の如く隔壁作用をしない，是等の事 貝については又題目を別にして最近の研究結果を照介する事として茲には高温に於て生成され ろ黑鈹 (mill-scale) について記迅する事とする。

$$
\begin{aligned}
& 2 \mathrm{Fe}(\mathrm{OH})_{3} \rightarrow \mathrm{Fe}_{2} \mathrm{O}_{3}+3 \mathrm{H}_{2} \mathrm{O} \\
& \mathrm{Fe}(\mathrm{OH})_{2} \longrightarrow \mathrm{FeO}+\mathrm{H}_{2} \mathrm{O} \\
& 2 \mathrm{Fe}(\mathrm{OH})_{3}+\mathrm{Fe}(\mathrm{OH})_{2} \longrightarrow \mathrm{Fe}_{2} \mathrm{O}_{3} \cdot \mathrm{FeO}+4 \mathrm{H}_{2} \mathrm{O} \longrightarrow \mathrm{Fe}_{3} \mathrm{O}_{4}+4 \mathrm{H}_{2} \mathrm{O}
\end{aligned}
$$

黑鈹は水の作用なく高温に於て鐵面が酸化されろ際に生成されるものである、著者の腐蝕の 定義から外に出てるろ化學反憵による生成物であるからえを錆と呼ぶ事は出來ない。しかし乍 ら之は上記の如く水其の他の水溶液によ万鐵の腐蝕の際に6生成されろ四三酸化鐵と全く同一 のちのであるからこの黑鈹を茲では黑錆と呼ぶ事にした次第である。高溫酸化によつて普通に 生成されろ黑鈹は水中で生成されるものに比して極のて緅密に瀻面に形成されるるので、之が 大氣中に於て相當に安定な 6 のであるからこの黑錆をちつて鐵面を完全に被覆してしまへば鐵

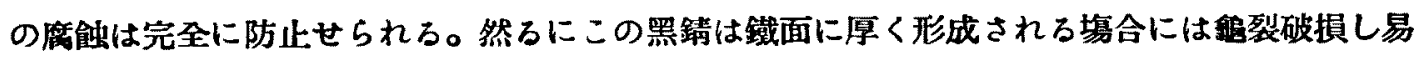
く、薄く形成される第合には氣密に鐵面を完全に萑ふ事が出來ないので防蝕作用の役目をさす 塲合には更にこの上にラノリン其の他の油脂を等布する事が普通であら。之を姴するに厚さを 浐當に緻密に形成されたものは防蝕効果の相當に大なるものであろ。故に今若しこの黑錆の中 に一點の鐵面が曝簬してるたとすれば辕面は黑錆に對して陽性であるから水分との接觸によつ て電池を形成し鐵面か陽场となつて痘痕狀に深く浸蝕されろ。この黑靕か鐵面に部分的に存在 すれば局部的の浸創を起し庢痕狀腐蝕即ち點蝕を起す。水中に於ては銅鐵船の船腹によく見ら れる所のものである。この現像は次の如き實驗によつて確證されてるる。即ち銶鐵の板をU字

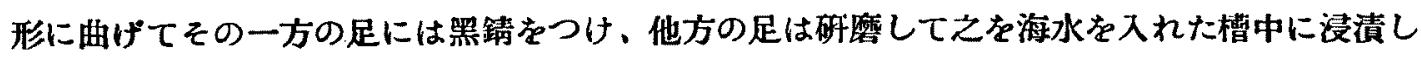

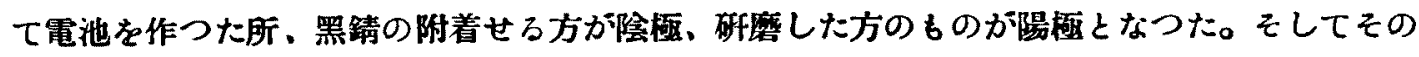


電動力は次第に弱り 4 日目には最初の檤の $\frac{1}{2} \overline{5}$ とつた。Farquharson 氏は二枚の鐵板の間に 海水を吸せた吸取り紙を挿入して最初その間の電位差を侧定し、次に一方の鐵板面を第一酸化 暂の粉で蔽ひ同樣な侧定をなした所前より $25 \%$ も大なる值を得た。炏に四三酸化鐵の所謂墨 錆の粉で蔽つた所 $560 \%$ と云ふ甚しく大なる値を示した。この結果より判断しても明に鐵面に この黑錆が部分的に附着してるると腐玲を促淮せしめる事が知れる。但し之をもつて鐵面を完 全に全部被覆してしまへば防錆の効果がある事は既述した通りである。貿際古くから鐵面にこ の四三酸化鐵を形成せしむる方法が研究せられて實際的にも應用せられてるる。即ち Barff, Bower, Wells, Gesner, Dewees-Wood, Bradley-Bontempi 氏等の方法がある。又他の樂品 を使用して之を形成せしむるものに Bertland, Ruffington 氏等の方法がある。倘ほ陸軍の軍

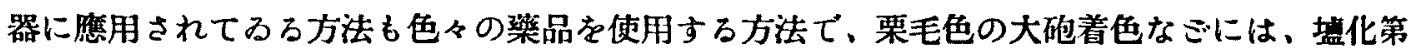

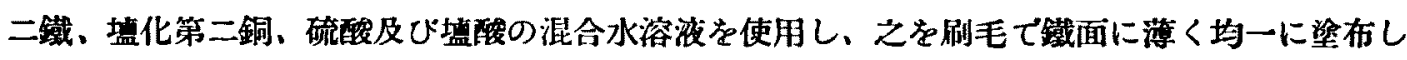
乾燥して生成する錆を鐵刷毛で取り、この方法を數回繰り返して鐵面全部に黑色皮膜を作る。

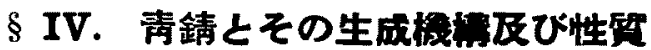

銅は大氣中に長く放置されておくと水分と岸酸瓦斯に會つて古色菅然たる所謂綠青を生ず る、この事は典人のよく知る所であるが、鐵が錆びて青くなると云ふ事に就ては初耳の人が

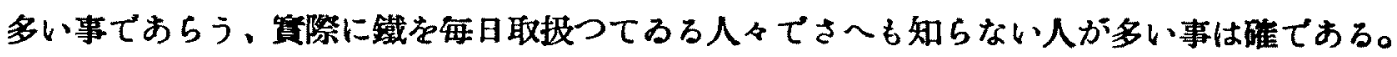
事筫鐵が錆びて直ちに青錆が出來ると云ふ事は殆んぶないのであが、地中なミに埋設されて ろろ瓦斯管の內部を見るとよく青藍色のブロシフ藍（prussian blue）の樣なるのがその内壁に

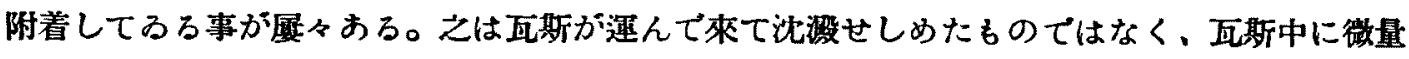
ではあるが含有されてるるチフン化水素が、鐵管の腐玲の初期に於て既に生成されてるる赤綪 と次の如き化學的反應を起して藍色の化合物を作らのである。隨つて斯栐に鐵にも青錆と呼ん でよいものが存在する譯である。

(1) $\mathrm{Fe}+2 \mathrm{H}_{2} \mathrm{O} \rightarrow \mathrm{Fe}(\mathrm{OH})_{2}+\mathrm{H}_{2}$

(2) $\mathrm{Fe}(\mathrm{OH})_{2}+2 \mathrm{HCN} \rightarrow \mathrm{Fe}(\mathrm{CN})_{2}+2 \mathrm{H}_{2} \mathrm{O}$

(3) $\mathrm{Fe}(\mathrm{CN})_{2}+4 \mathrm{HCN} \rightarrow \mathrm{H}_{4}\left[\mathrm{Fe}(\mathrm{CN})_{6}\right]$

(4) $2 \mathrm{Fe}(\mathrm{OH})_{2}+\mathrm{H}_{4}\left[\mathrm{Fe}(\mathrm{CN})_{6}\right] \longrightarrow \mathrm{Fe}_{2}\left[\mathrm{Fe}(\mathrm{CN})_{6}\right]+4 \mathrm{H}_{2} \mathrm{O}$

(5) $6 \mathrm{Fe}\left[\mathrm{Fe}(\mathrm{CN})_{6}\right]+3 \mathrm{O}_{2}+6 \mathrm{H}_{2} \mathrm{O} \longrightarrow 2 \mathrm{Fe}_{4}\left[\mathrm{Fe}(\mathrm{CN})_{6}\right]_{8}+12 \mathrm{H}_{2} \mathrm{O}$

更に自然に生成されらのではないか人工的に防蝕皮膜として化學的に薄い綠色の化合物を鐵 面に形成せしめる事が州來る。天然、自然に生成されるのではないから錆と呼ぶ事が出來ない かる知れない、しかし黑錆と同㧼人工的に防刢皮膜として生成し得られ極めて有効なものであ

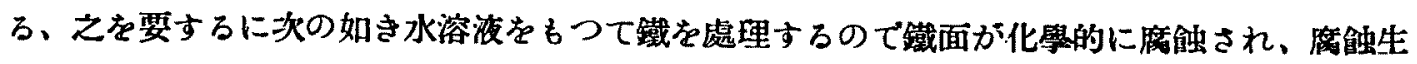


成物が表面に生成されるものであるから人工的ではあるが鐵面が青色に錆びるものであから 敢て青錆と呼んでも惡くはない、この沈溉物が本當の青錆で上記瓦斯管內に出來るものは藍錆 であ。

この青錆る形成せしめる創案者は Coslett $^{(8)}$ 氏で其の後 Parker 氏によつて改良せられ著 者(の) も亦溶液中に附着能の强いマンガンの燐酸盐を多量に混合して之を改良した。その要領は

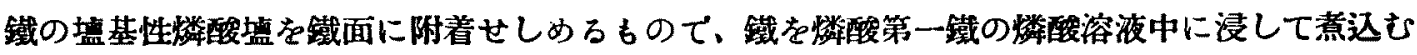
のである。先づ燐酸の水溶液に燐酸第一鐵を飽和に溶解し、えに清淨にした辂片を入れ・ば鐵 面は溶解して水素を發生する、この際溶液は燐酸鐵については過飽和となるため清淨な鐵面に

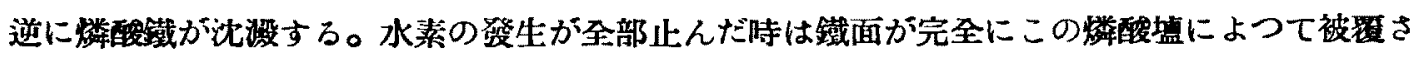
れた譯である。この際溶液に過酸化マンガンの如き酸化乵を入れろ事が Parker 氏の改良て、

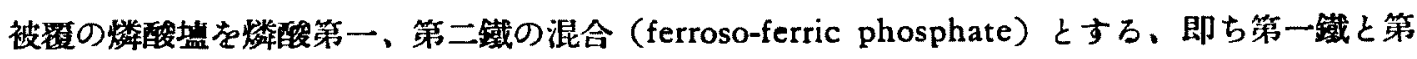
二轼の比を $3: 1$ の割に形成せしめろ事が改良である、斯くして丈夫な密着力の强い靑錆即ち 燐酸鐵の皮膜が形成される。防蝕効果を大ならしめろにはこの上に更にパラフィン油を塗布し てるろが著者はアルカリで中性としたコールタールを燒きつけて黑色皮膜として大なる効果を 得てるろ。斯くして防蝕したものは大或中は刎論海水中に於ても極めて有効なるものておる。

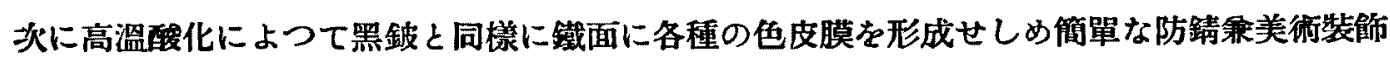

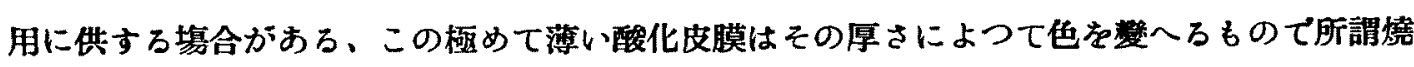
厌色 (temper color) として有名である。その酸化膜の厚さは加愁の温度と時間によつて暴る 事は勿諭て温度と色との關係を示すと大體次の如くである。

\begin{tabular}{|c|c|}
\hline $220^{\circ} \mathrm{C} \ldots \ldots \ldots$ pale yellow & 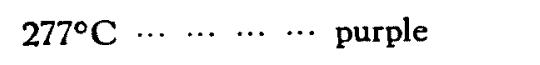 \\
\hline $230^{\circ} \mathrm{C} \ldots \ldots \ldots \ldots$ straw yellow & $288^{\circ} \mathrm{C} \ldots \ldots \ldots \ldots$ light blue \\
\hline $55^{\circ} \mathrm{C} \cdots \cdots$ & $293^{\circ} \mathrm{C} \ldots \ldots \ldots \ldots$ dark blue \\
\hline ‥ purple yellow & $316^{\circ} \mathrm{C} \ldots \ldots \ldots \ldots$ blackish blue \\
\hline
\end{tabular}

防蝕効果を出すためにはザボンエナメルの如きた染布すればその効果线分强める事が出來る が完全なものと云ふ事は出來ない。

上上各種の色をもつ沈瀿物又は高溫酸化によろ酸化物が化學的に钱面に形成されたものであ ろので廣義の意味で錆と呼ひ輯錄した次第である。

\section{$\S$ V. 總括}

1. 赤錆は鐵鋼の噟蝕作用に重大なる作用を及ぼすものであるから、先づそについてその水

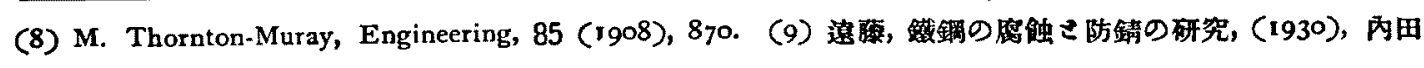

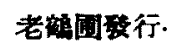


中に於けろ生成の機栫を迅べ、更に大氣中に於ける生成機作として吸濕性浮游固體微粒子によ ろ大氣中の腐蝕促進作用について考へた。

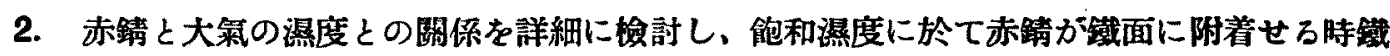

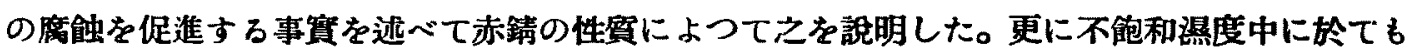

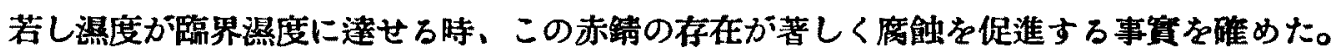

3. 臨界濕度に於て赤靕の附着が腐蝕を促進すると云ふVernon 氏の實駼結果を检討した、 この臨界濕度で赤錆が急激に潮解性を大にするものでない事、更にこの點で赤錆中の水分は嚾 に 5〜7\%の坦加に過ざない事、それにも拘はらす何故この臨界滋度で急激に腐蝕が促進され ろか、赤錆がゲル狀組織でこの點で急に物理的條件が謷化すると云ふ Patterson と Hebbs 雨 氏の說で䛃明した。

4. 黑鈹即ち高温加工中に琙の表面に出來ろものを黑錆と呼び、えが水中で生成されるマグ ネタイトと同一物なる事を还べ、黑鈹双はハンマースタールの防蝕効果又は局部的度蝕の原因 となる事を記远した。仯ほ各種混合棨品の水溶液によつて人工的にこの四三酸化鐵即ち黑錆を 形成せしめ得る事を併記した。

5. 青錆として先つ地下埋設された瓦斯鐵管の內部にプロシフ監に似た藍錆の生成せる事を 述べ、之が生成の原因を检討せる結果を略述した。更に人工的に鐵の表面に靑色の燐酸第一鐵 と第二鐵の混合物を形成せしめるコスレット法を述心゙、そも一種の青靕と呼び、その防蝕効果 の大なろ事を迹べた、更に燒戻色を的する極めて薄い酸化皮膜につき一言し、温度と色との關 係の大略を阱記しだ。(未完) 